\title{
Attitudes of Faculty Staff and Students Towards the Experience of Distance Learning During COVID-19 According to Learning Outcomes: A comparative Study Between Faculty of Education and Faculty of Tourism and Hotels, Fayoum University
}

\author{
Mohammed Ahmed Owees Ali Abdullah ${ }^{\mathrm{a}}$, Marwa Sayed Wahba Mahmoud ${ }^{\mathrm{b} *}$, Azza Abd Elmonem Abd Elatti Ali ${ }^{\mathrm{b}}$ \\ ${ }^{a}$ Faculty of Education, Fayoum University, Egypt \\ ${ }^{b}$ Faculty of Tourism and Hotels, Fayoum University, Egypt
}

\section{ARTICLE INFO}

Keywords:

COVID-19

Pandemic

Distance Learning

Learning Outcomes

\begin{abstract}
The world is currently witnessing a major event that may threaten education with a tremendous crisis, perhaps the most dangerous in our contemporary times, which is the emerging COVID-19 crisis, as schools and university faculties have adopted the method of distance learning to overcome this crisis by giving virtual lectures and enabling students to follow lectures in their homes via Computers, and had it not been for this epidemic pandemic, our schools and universities would not have distance learning in the manner imposed by the circumstances of this pandemic. The study was aimed at recognition the attitudes of faculty staff and students of Fayoum University towards the experience of Distance learning in light of the COVID-19 pandemic according to learning outcomes, the study reached a set of results, including The distance learning experience in light of COVID-19 pandemic has contributed to achieving a set of educational advantages in all elements of the curriculum system and the educational process for faculty staff and the assisting body in various aspects also distance learning faces some challenges such as the immature infrastructure, unawareness, resistance to change, and computer/Internet illiteracy.
\end{abstract}

(C2020 Faculty of Tourism and Hotels, Fayoum University All rights reserved

\section{Introduction}

COVID-19 has affected different sectors in society, and education is not an exception. Schools and higher education institutions were among the most affected sectors (Haider \& Al-Salman, 2020). Governments around the world have moved to suspend that face to face teaching in schools is affecting about $95 \%$ of the world's student population; the largest disruption to education in history (Engzell, Frey \& Verhagen,2020) As a result, various schools, faculties, and universities have discontinued in face to face teaching because

\footnotetext{
*Corresponding author: email: msw00@fayoum.edu.eg
}

there was an urgent need to protect and save our students, academic staff, communities, societies, and the nation as a whole (Dhawan, 2020).

Certainly, like many other parts of everyday life, COVID-19 has had a critical impact on students, instructors, and educational organizations around the world. The pandemic has caused schools, faculties and universities across the globe to close so that students could follow the social distancing measures (Adnan \& Anwar, 2020 ). In addition, in response to COVID-19, different countries have applied strict social distancing measures and a lockdown policy. Certainly, this 
pandemic has had a great impact on schools, students and teachers (Almanthari, Maulina, \& Bruce, 2020). The closure of educational institutes aiming at the public health emergency is a contagion effect of the novel Coronavirus.

In response to the educational institutions closure situation caused by COVID-19, the UNESCO has recommended the educational institutes to become prepared them with online learning tools (Shehzadi et al., 2020). Today, the majority of distance education takes place using the Internet, it becomes easy to access for the large majority of students whether in their own homes or at facilities such as local libraries. Distance learning, thus, seems be more flexible and often includes more technologies that can give learners the opportunity to interact with instructors and other learners effectively and flexibly (S. El-Seoud, TajEddin, Seddiek, Ghenghesh, \& El-Khouly, 2014).

In Egypt, as a case, COVID-19 pandemic has affected faculties, students, and teachers and the Ministry of Higher Education has recognized the needs for implementing distance learning in public universities Therefore, schools that have limited or no experience with distance learning and schools that were not prepared for distance learning resources have experienced difficulties, especially, when teachers do not understand how to use online applications (Almanthari et al., 2020)

Yet, little research has been done to verify the process of how university students adopt and use e-learning. University students' persistent frustration in webbased education is another problem in terms of online learning. This drives more student-centered research of online education. There are, however, numerous barriers to the integration of instructional technology into higher education, such as technology infrastructure, faculty effort, technology satisfaction, and graduates' competency (Park, 2009).

Therefore, the main purpose of this study is to investigate the attitudes of faculty staff and students of Fayoum University towards the experience of Distance learning during the Corona pandemic according to the learning outcomes.

\section{Literature review}

Previously, higher education institutions have initiated the creation of enterprise open-source applications such as course management systems and electronic portfolios. These distance learning applications . Distance learning is believed to take a competitive advantage over the conventional methods due to the speed and efficiency of the Internet, especially in to maintain the teaching and learning process. Universities have implemented distance learning despite having little or no experience in distance learning and being not prepared for e-resources needed for the teaching and learning process. Thus, they have been encountered by a lot of difficulties and obstacles, especially when teachers and students do not understand how to use online application (Elgahsh \& Diab, 2020). This matter made the teaching professionals think of alternative methods of teaching during this lockdown. In turn, this paved the way towards web-based learning or e-learning or online learning.

The teaching/learning process has stepped into the digital world in which teaching professionals and students are virtually connected in a practical way (Radha, Mahalakshmi, Kumar, \& Saravanakumar, 2020). However, the implementation of distance learning is not always easy and effective. During the COVID-19 outbreak, schools and universities have quickly implemented distance learning.

initiatives are the first steps that higher education has taken to move away from proprietary software toward open sources (Koohang \& Harman, 2005).The development and progress in the field of educational technology has led to the emergence of many technological innovations. Their employment in the field of the educational process has become an urgent necessity to take advantage of them in raising the efficiency of the educational process (Ahmed, 2012). Most distance learning programs reflect a reconstruction of the educational agenda from a closed environment to one where there is an open flow of information based on an integrated, process-oriented instructional approach. Distance learning environments are designed to offer opportunities for sharing information, to cater to students with a variety of learning styles, and to allow for choices in information representation (Kaur \& Zoraini Wati, 2004). Distance learning means learning anywhere, and at any time. Therefore, it is important to point out that the impact of distance learning has been felt in education, economic sector, social sphere, health sector, and generally it has impacted the whole world (El-Seoud et al., 2014).

Distance learning is the alternative of traditional education and it can also be a complementary to it (Kumar Basak, Wotto, \& Belanger, 2018)

making announcements. Moreover, distance learning could be the dream for people with work or family commitments; due to the high flexibility in time and 
place it offers (El Gamal \& Abd El Aziz, 2011) The most attractive feature of distance learning is that it is student-centered. It accommodates individual preferences and needs. At the same time, it empowers students of various backgrounds to have equal access to the best resources and referral material, lecture sessions, tutoring, and experienced teachers (Wani, 2013). Distance learning has been widely used as a tool in the learning process in most Egyptian universities. In spite of its importance, many of the academic staff in these universities still tends to avoid using it or using it only to upload materials and neglect the interactive activities offered by such systems (ElSeoud, El-Sofany, Taj-Eddin, Nosseir, \& El-Khouly, 2013).

\subsection{Operational definition of Distance learning}

There are several definitions of Distance learning, According to (Alqahtani \& Rajkhan, 2020), for instance, distance learning is 'the use of various technological tools that are web-based, web distributed, or web capable for education'. While El Zayat ( 2008) stated that Distance learning is "the delivery of a learning, training or education program by electronic means distance learning involves the use of a computer or electronic device (e.g. a mobile phone) to provide training, educational or learning material. Finally, distance learning can be referred to as the use of information and communication technologies to enable the access to online learning/teaching resources (Arkorful \& Abaidoo, 2015).

According to Lwoga (2012) distance learning has five main characteristics:

1. Learning takes place anytime and anywhere, not only in the classroom.

2. Learners take on the role of organizers. Instructors serve as both the distributors of educational content and facilitators of the learning process.

3. Learning is a lifelong process and thus it is not solely linked to educational institutions.

4. Learning happens in communities of learning or communities of practice. Learners participate in formal as well as informal communities.

5. Learning is informal and non-formal, takes place at home, in the workplace and during leisure time, and is no longer centered on teachers or institutions.

In light of the previous definitions, researchers can define distance learning as "any type of learning that depends on electronic communication between the student and the lecturer, using the various technological tools and services provided by the Internet that facilitate the arrival of information to the student and raise his motivation to learn through multiple technological influences provided by those services; which makes the learner have an active, positive role in obtaining information, and the role of the lecturer is limited to the process of supervision, direction, guidance, and evaluation of all learning elements".

\subsection{Benefits of Distance learning}

The internet is a technological development that has the potential to change, not only the way society retains and accesses knowledge but also to transform and restructure traditional models of higher education, in particular the delivery and interaction in and with course materials and associated resources (Wani, 2013).Using distance learning has many benefits, such as: using the web as an electronic library, encouraging the students to learn about IT implementation, and having experience about document information management, such experience is needed for other disciplines, increase the ability of auto-training (ElSeoud et al., 2013). The most important advantage of distance learning is that one can pursue his choice of education at any time of his life. There is no control about the city, faculty, etc. Distance learning makes it much easier for some students to complete a degree or get additional job training while balancing work and family commitments. Because the hours when class work can be completed are flexible (Vlasenko \& Bozhok, 2014; El Zayat, 2008). It is able to provide opportunities for relations between learners by making use of discussion forums. Through this, e-learning helps eliminate barriers that have the potential of hindering participation including the fear of talking to other learners also it motivates students to interact with other, as well as exchange and respect different point of views (Arkorful \& Abaidoo, 2015).

Distance learning in Egypt could provide solutions to problems such as overcrowded classrooms and transportation problems (El Gamal \& Abd El Aziz, 2011). Also it can thus improve teaching and learning practices in higher education if appropriately deployed, taking into consideration the pedagogical issues (Lwoga, 2012; El-Seoud et al., 2014) stated that distance learning technologies (1) have a positive impact on course delivery and student learning, (2) are effective at achieving greater student participation and student interest, and (3) allow opportunities to improve critical thinking.

\subsection{Disadvantage of Distance learning}


One of the main disadvantages of distance education is the loss of interaction with other students in the classroom. In distance learning, study in a group is difficult, one just must do it by himself which becomes publicly one-off as there is no communication with other classmates (Vlasenko \& Bozhok, 2014). Also, distance learning may negatively impact socialization skills and limit the role of instructors as directors of the educational process and may also be subject to piracy, plagiarism, cheating, inadequate selection skills, and inappropriate use of copy and paste (Arkorful \&. Abaidoo, 2015). In addition, it was mentioned that one of the difficulties of distance learning is the marked weakness in the infrastructure, the lack of financial means that support this type of education, and the lack of conviction in it as an alternative to traditional education (Hayah, 2019). As well as lack of knowledge of the necessary skills to use modern technologies in addition to the weak response of learners to the new pattern and their interaction with it, and the insufficiency of qualified human cadres, weakness in the efficiency of some teachers in using technology and employing it in the educational process (Hantoly, 2016).

In Egypt, distance learning has many challenges, some of which are the immature infrastructure, unawareness, resistance to change, and computer/Internet illiteracy. Yet, it is essential that the Egyptian government considers e-learning, especially in higher education, where most of the problems originate; in order to meet the needs of increasing numbers of students and cover the requirements of the job market in a period of communication and knowledge revolution (El Gamal \& Abd El Aziz, 2011)

So, Faculty staff prefers to use pen and paper and faceto-face instruction. There are also considerable technological infrastructure difficulties, which limit developments Furthermore, a lack of IT skills is considered to be one of the main reasons for student non-participation in distance learning (El-Seoud et al., 2014)

\section{Figure 1.}

\section{Some advantages and disadvantage of distance learning}

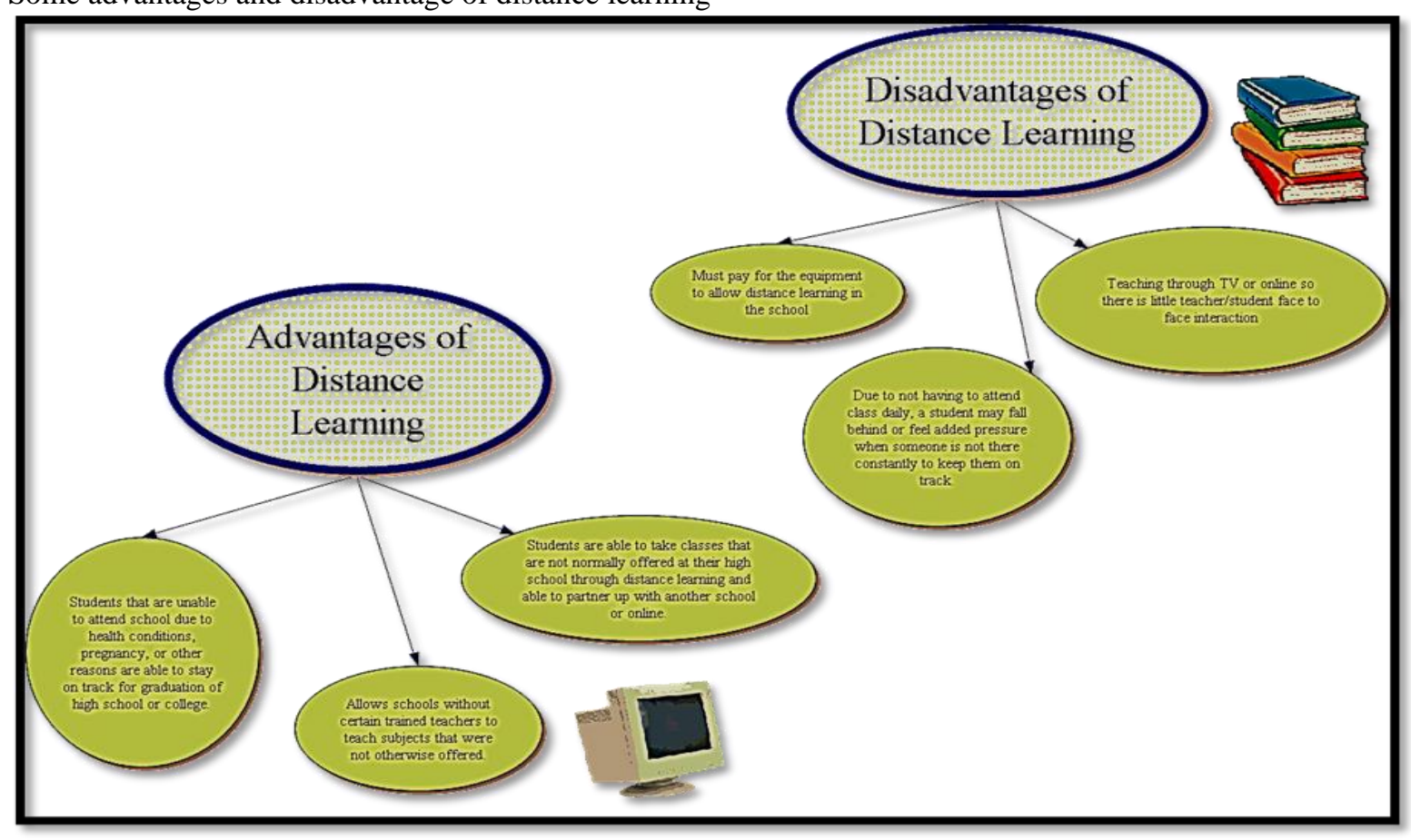

\subsection{Learning Outcomes}

Learning outcomes are an important element of the educational process. They bring more transparency to education systems and qualifications. The term "learning" means gaining knowledge, understanding or skills required by study or experience (Merriam Webster dictionary, 2007), where 'Outcomes' are what one ends up with intended or not, after some form of engagement (Eisner, 1979). Also, according to Allan (1996), outcomes refer to what learner or student actually achieve.

In this sense, there are many definitions for the term "learning outcomes". Otter (1992), defined learning outcomes as what a learner knows or can do because of learning. Cedefop (2011) also defined this term as a 
statement of what a learner knows, understands, and is able to do on completion of a learning process, which is defined in terms of knowledge, skills, and competence. Another definition to this term is also provided which referred to it as a 'set of knowledge, skills, and or competences which an individual has acquired or is able to demonstrate after completion of a learning process.

Based on these definitions, learning outcomes refer to the benefits and personal changes that the learner acquired and what is expected from the learner to do after completion of learning process. The benefits and changes of the learners can be measured in terms of the abilities and achievements.

\subsection{The characteristics of learning outcomes}

There are many characteristics of learning outcomes. First, it could identify especially what should be learned. Second, it provides guidelines for content, instructions, and assessment. Third, it focuses on learning rather than teaching. Fourth, it should be shared with the learner to make it transparent. Fifth, it must be measurable, and achievable. Sixth, it should connect directly to the assessment criteria that are used to judge achievement. Seventh, it helps to improve the quality of learning, education, and training. Therefore, learning outcomes are necessary for any unit outline.

\subsection{How to use Learning Outcomes in the Educational Process}

When you are intending to write about learning outcomes statements, there are several essential points that should be considered. First, learning outcomes should be treated as an interactive process starting from all objectives and moving towards specific statements for units and assessment. This involves students' perspectives, what should students able to know and do after finishing their study. Second, it should focus on what important and avoid trivial things. This means that an outcome statement should consider the skills, attitudes, values, and abilities that demonstrate the attainment of that outcome. Third, addressing and focusing on learners (Cedefop, 2017). Fourth, it should start the statement of learning outcomes with an action verb. For cognitive outcomes, verbs should go beyond knowledge and comprehension. Using these verbs help to make learning outcomes measurable. Fifth, the numbers of statements should be limited for defining and writing learning outcomes and course or unit or a program. This is because it helps to facilitate the process of learning, planning, teaching easily, and carrying out an assessment in a proper way. Sixth, writing an action verb should be followed by writing the object of the verb as well as statement specifying the depth and breads of learning process (Nusche, 2008).

\subsection{The Taxonomy of Learning Outcomes}

Learning outcomes have many dimensions, some of them are easier to measure and assess than others. Thus, there is no a certain assessment that can measure all learning outcomes. There are three basic domains of learning outcomes which are cognitive, practical, and emotional domains.

\subsubsection{The Cognitive Domain}

Cognitive is a major domain of learning outcomes. It means the recognition of knowledge, skills, and the development of intellectual abilities (Posner, 1992). It also "ranges from domain specific knowledge to the most general of reasoning and problem-solving skills" (Shavelson \& Hunag, 2013). There are many categorizations of cognitive domain and most of them relies on Bloom's taxonomy (1965) of educational objectives.

Cognitive domain includes many levels of cognitive knowledge ranging from remembering to evaluating knowledge. The first level is remembering knowledge which means recalling information, materials, and ideas of a specific phenomenon (Bloom, 1965). The second level is comprehension which means that student can translate, interpret, and extrapolate information and study material that he studied. The third level is an application which means the use of generalization in specific instances. The student at this level can use the previous knowledge and skills in solving a new problem or a new situation.

The fourth level is analysis which refers to determining the relationship between parts of a phenomenon. The student should be able to analyze the information and events to smaller parts. The fifth level is synthesis which means creating new relationship between information and ideas in a new situation. The last level is evaluation which means the ability of student to exercise learned judgment.

\subsubsection{The practical Domain}

The practical domain is the second basic domain of learning outcomes. It refers to the ability to do rapid and accurate task. The learning outcomes in this domain focus on skills that need a balance in using students' muscles in doing certain tasks (Sahrawi \& Shabouh, 2018). It has five levels, ranging from imitation to naturalization. The first level is imitation, which means observing certain events or skills and tries to imitate it. The student observes the behavior 
of another person and imitating it. This is considered the first step in learning a complex skill. The second level is a manipulation, which refers to the ability of the learner to perform certain actions by following instructions to practice skills.

The third level is precision which means the ability to perform a task with few mistakes and become more precise without the presence of the original source. The new skill has been attained and proficiency is marked by smooth and accurate performance. The fourth level an articulation which means the ability to co-ordinate range of actions by combining two or more skills. The fifth level is naturalization, which refers that the learner shows a high level of performance naturally. These skills are combined, sequenced, and performed consistently with ease (Kennedy, 2006).

\subsubsection{The Emotional Domain}

Emotional domain is the third basic domain of learning outcomes. It refers to students' outcomes related to attitudes, values, and interests. It has five levels ranging from receiving phenomena to internalizing values. The first level is receiving a phenomenon, which is the lowest level of this domain. It refers to the willingness and attention to a certain phenomenon among many other phenomena. The second level is responding to a phenomenon, which means reacting and voluntary participating to this phenomenon. In this level, the students' interests are formed. Therefore, the educational objectives at this level be called the objectives of interests and appreciation.

The third level is valuing, which refers to giving value to certain phenomena or behaviors. Students express their persuasion and mastering of this skill through commitment behaviors in specific situations. The fourth level is organization which means rearrangement of the value system. A student at this level starts to establish a self-new value system. They start to accrue conceptualize value and then compare these values and determine relationship between these values (Kennedy, 2006). The fifth and last level is internalizing values, which means incorporating values into life. At this level, individualism of students comes to appear. Student becomes to have a distinct personality.

In light of the previous presentation, the researchers see that the learning outcomes are very important in the educational process, and that they are integrated and intertwined so that they ultimately lead to the occurrence of learning in the student, as well as pouring all the aspects: cognitive, practical, and emotional in the social aspect, which makes this student adapted to his environment and to the society in which he lives, which is what this study tried to clarify and confirm. The vision of Egypt 2030 aims to develop these educational outcomes in the behavior of the university students by means of distance learning, and to employ it in the service of the educational process, especially in application to the community of two faculties in Fayoum University; the Faculty of Education, which is the oldest faculty in the university, and the Faculty of Tourism and Hotels, which is one of the newest faculties in the university's establishment. In addition, both faculties have obtained quality and academic accreditation certificates. This makes the students of these two faculties and their academic community unique in nature, which this study aims to achieve.

\section{Methodology}

In March 2020, the Egyptian government suspended face-to-face learning in all universities. After two months of only online learning, a questionnaire was distributed to students and staff of tourism and hotels faculty and education faculty in Fayoum University. The questionnaire of faculty staff was comprised of seven parts. The first part contains 4 items related to the advantages of distance learning in the educational process. The second part contains 9 items related to academic content in distance learning; third part contains 6 items related to educational and technological means used in distance learning; fourth part contains 7 items related to teaching methods used in distance learning; fifth part contains 6 items related to evaluation methods used in distance learning; sixth part contains 12 items related to faculty support for the distance learning experience; seventh part contains 13 items related to barriers to distance learning .

The questionnaire of students consists of five parts. First part contains 11 items related to the cognitive aspect of distance learning; second part contains 10 items related to the emotional aspect of distance learning; third part contains 8 items related to the skill aspect of distance learning; fourth part contains 11 items related to the social aspect of distance learning; fifth part contains 10 items related to barriers to distance learning.

A five-point Likert scale was used for measuring all items (strongly agree; agree; neutral; disagree; and strongly disagree). The questionnaire was accessed on Google form. A total of 514 students of faculty of tourism and hotels and faculty of education 
participated in this study. A total of 183 staff of tourism and hotels faculty and education faculty participated in this study. The obtained data will be analyzed by using SPSS version 23 .

\subsection{Hypotheses}

H1: There are no statistically significant differences between the faculty staff attitudes towards the distance learning experience considering the Corona pandemic between the Faculties of Education \& Tourism and hotels.

H2: There are no statistically significant differences between the students' attitudes towards the distance learning experience in light of the Corona pandemic between the Faculties of Education \& Tourism and hotels.

\section{Findings}

\subsection{The validity and reliability}

The researchers used Cronbach's alpha value to tested the reliability of the data. The result outlines that the alpha coefficient value for all variables of the faculty staff questionnaire was 0.938 . The result outlines that the alpha coefficient value for all variables of the students' questionnaire was 0.906 . the results indicate that all coefficient values were greater than 0.6 . So, the research measurements were reliable and acceptable (Mohamad et al., 2015).

4.1. The internal consistency of the questionnaire of faculty staff

\section{Table 1}

The correlation matrix among faculty staff questionnaire variables

\begin{tabular}{|c|c|c|c|c|c|c|c|c|c|}
\hline \multirow[t]{9}{*}{$\begin{array}{l}\text { Spear } \\
\text { man's } \\
\text { rho }\end{array}$} & & Total & $\begin{array}{l}\text { Advantages } \\
\text { of distance } \\
\text { learning }\end{array}$ & $\begin{array}{l}\text { Academi } \\
\text { c content }\end{array}$ & $\begin{array}{l}\text { Educational } \\
\text { \& } \\
\text { technological } \\
\text { means }\end{array}$ & $\begin{array}{l}\text { Teaching } \\
\text { methods }\end{array}$ & $\begin{array}{l}\text { Evaluation } \\
\text { methods }\end{array}$ & $\begin{array}{l}\text { Faculty } \\
\text { support }\end{array}$ & Barriers \\
\hline & Total & 1 & $0.785 * *$ & $0.889 * *$ & $0.861 * *$ & $0.858 * *$ & $0.879 * *$ & $0.920 * *$ & $-0.213 * *$ \\
\hline & $\begin{array}{l}\text { Advantages of } \\
\text { distance } \\
\text { learning }\end{array}$ & $0.785 * *$ & 1 & $0.814 * *$ & $0.741 * *$ & $0.639 * *$ & $0.672 * *$ & $0.702 * *$ & $-0.388 * *$ \\
\hline & $\begin{array}{l}\text { Academic } \\
\text { content }\end{array}$ & 0.889 & $0.814 * *$ & 1 & $0.840 * *$ & $0.770 * *$ & $0.736^{* *}$ & 0.806 & $-.420 * *$ \\
\hline & $\begin{array}{l}\text { Educational \& } \\
\text { technological } \\
\text { means }\end{array}$ & $0.861 * *$ & $0.741 * * * *$ & $0.840 * *$ & 1 & $0.825 * * *$ & $0.777 * *$ & $0.790 * *$ & $-.498 * *$ \\
\hline & $\begin{array}{l}\text { Teaching } \\
\text { methods }\end{array}$ & $0.858 * *$ & $0.639 * *$ & $0.770 * *$ & $0.825 * *$ & 1 & $0.843 * *$ & $0.808 * *$ & $-0.491 * *$ \\
\hline & $\begin{array}{l}\text { Evaluation } \\
\text { methods }\end{array}$ & $0.879 * *$ & $0.672 * *$ & $0.736^{* *}$ & $0.777 * *$ & $0.843 * *$ & 1 & $0.827 * *$ & $-0.369 * *$ \\
\hline & $\begin{array}{l}\text { Faculty } \\
\text { support }\end{array}$ & $0.920 * *$ & $0.702 * *$ & $0.806 * *$ & $0.790 * *$ & $0.808 * *$ & $0.827 * *$ & 1 & $-0.359 * *$ \\
\hline & Barriers & $-.213 * *$ & $-.388 * *$ & $-.420 * *$ & $-.498 * *$ & $-0.491 * *$ & $-0.369 * *$ & $-0.359 * *$ & 1 \\
\hline
\end{tabular}

** Correlation is significant at the 0.01 level (2-tailed). $\quad$ * Correlation is significant at the 0.05 level (2-tailed)

From the previous table, it is noticed that that the other and to the total at the level of 0.01., and this variables of the questionnaire are correlated to each indicates the internal consistency of the questionnaire

\subsection{The internal consistency of the questionnaire of students}

\section{Table 2}

The correlation matrix among students' questionnaire variables

\begin{tabular}{|l|l|l|l|c|c|c|c|}
\hline \multirow{2}{*}{$\begin{array}{l}\text { Spear } \\
\text { man's } \\
\text { rho }\end{array}$} & Total & $\begin{array}{l}\text { Cognitive } \\
\text { aspect }\end{array}$ & $\begin{array}{l}\text { Emotional } \\
\text { aspect }\end{array}$ & Skill aspect & $\begin{array}{l}\text { Social } \\
\text { aspects }\end{array}$ & Barries \\
\cline { 2 - 8 } & Total & 1 & $0.761^{* *}$ & $0.830^{* *}$ & $0.794^{* *}$ & $0.833^{* *}$ & $0.283^{* *}$ \\
\cline { 2 - 8 } & Cognitive aspect & $0.761^{* *}$ & 1 & $0.575^{* *}$ & $0.486^{* *}$ & $0.523^{* *}$ & $0.143^{* *}$ \\
\cline { 2 - 8 } & Emotional aspect & $0.830^{* *}$ & $0.575^{* *}$ & 1 & $0.644^{* *}$ & $0.627^{* *}$ & $0.283^{* *}$ \\
\cline { 2 - 8 } & Skill aspect & $0.794^{* *}$ & $0.486^{* *}$ & $0.644^{* *}$ & 1 & $0.659^{* *}$ & $0.218^{* *}$ \\
\cline { 2 - 8 } & Social aspects & $0.833^{* *}$ & $0.523^{* *}$ & $0.627^{* *}$ & $0.659^{* *}$ & 1 & $0.220^{* *}$ \\
\hline & Barriers & 0.019 & $0.143^{* *}$ & $0.283^{* *}$ & $0.218^{* *}$ & $0.220^{* *}$ & 1 \\
\hline
\end{tabular}

**Correlation is significant at the 0.01 level (2-tailed).

*Correlation is significant at the 0.05 level (2-tailed). 
From the previous table, it is noticed that the level of all significance is greater than 0.05 , and then there are no statistically significant differences between the responses of the study sample of faculty staff between the Faculties of Education and Tourism, and then the zero hypothesis is accepted and the alternative hypothesis is rejected. figure (2) illustrates these differences

Fig. 2.

The difference between the responses of faculty staff in the Faculties of Education and Tourism regarding distance education

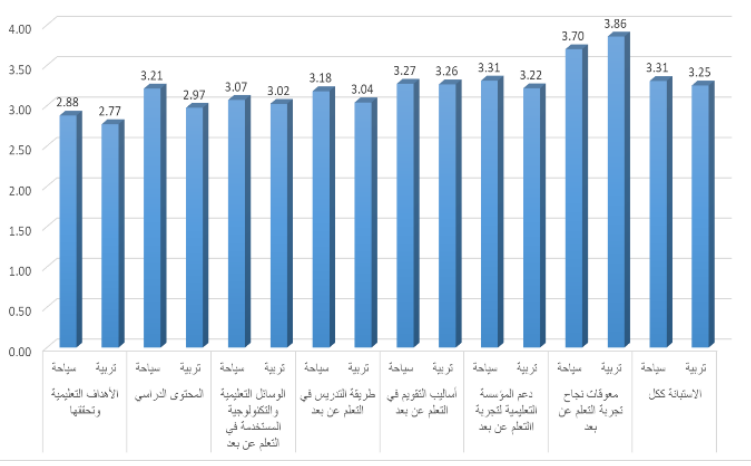

Results in figure (2) indicated grand mean of the responses of faculty staff in the faculty of Education regarding distance education was 3.25 and grand mean of the responses of faculty staff in the Faculty of Tourism regarding distance education was 3.31.

The previous findings give proof of the validity of the first hypothesis that "There are no statistically significant differences between the faculty staff 's attitudes towards the Distance learning experience in light of the Corona pandemic according to the learning outcomes in each of the Faculties of (Education, Tourism and Hotels) at Fayoum University

\section{Table 4}

Disadvantages of distance learning

\begin{tabular}{|c|c|c|c|c|}
\hline Disadvantages of distance learning & Mean & Std. deviation & Arrangement & Attitude \\
\hline $\begin{array}{l}\text {-There are problems and obstacles encountered while implementing } \\
\text { the distance education experience. }\end{array}$ & 3.754 & 3.295 & 9 & Agree \\
\hline $\begin{array}{l}\text {-Poor Internet service available to me, which led to the disruption of } \\
\text { many electronic assignments for students }\end{array}$ & 3.885 & 3.384 & 5 & Agree \\
\hline -My experience is weak in dealing with some internet services & 3.240 & 3.537 & 13 & Neutral \\
\hline $\begin{array}{l}\text {-The absence of direct interaction between the faculty staff and the } \\
\text { student reduces the effectiveness of the learning process. }\end{array}$ & 4.115 & 3.450 & 2 & Agree \\
\hline $\begin{array}{l}\text {-I believe that distance learning eliminates or reduces my role in the } \\
\text { learning process }\end{array}$ & 3.508 & 3.644 & 11 & Agree \\
\hline $\begin{array}{l}\text {-Conflict in the dates of broadcasting lectures to students, and the } \\
\text { overlapping of lectures of the various subjects without regulation by } \\
\text { the educational institution. }\end{array}$ & 3.831 & 3.673 & 8 & Agree \\
\hline $\begin{array}{l}\text {-The difficulty of uploading all files in different formats and } \\
\text { extensions to the educational website, and in most cases only Word or } \\
\text { PDF files are downloaded }\end{array}$ & 3.842 & 3.710 & 6 & Agree \\
\hline $\begin{array}{l}\text {-Distance learning represents an additional burden on me in preparing, } \\
\text { implementing, and evaluating learning over traditional learning. }\end{array}$ & 3.464 & 3.828 & 12 & Agree \\
\hline -Poor interaction of students with the submitted electronic content. & 3.842 & 3.839 & 6 & Agree \\
\hline -Lack of functioning internet for some students & 4.290 & 3.839 & 1 & $\begin{array}{l}\text { Strongly } \\
\text { agree }\end{array}$ \\
\hline $\begin{array}{l}\text {-The problem of sudden power outages; Which prevents the } \\
\text { completion of the educational process }\end{array}$ & 3.754 & 3.945 & 3 & Agree \\
\hline $\begin{array}{l}\text {-Difficulty achieving all the objectives of the educational course } \\
\text { through distance learning }\end{array}$ & 3.885 & 4.025 & 4 & Agree \\
\hline $\begin{array}{l}\text {-The absence of a distance education culture among some faculty } \\
\text { staff. }\end{array}$ & 3.240 & 4.162 & 10 & Agree \\
\hline
\end{tabular}


many obstacles that faced faculty staff in applying distance learning, and the most important of these obstacles was Lack of functioning internet for some students, The absence of direct interaction between the faculty staff and the student reduces the effectiveness of the learning process the problem of sudden power outages; Which prevents the completion of the educational process and Difficulty achieving all the objectives of the educational course through distance learning and this is consistent with a study of (Ben Ali,2016).

\subsection{The responses of students to the questionnaire}

In order to compare the students, attitudes towards the distance learning experience in light of the Corona pandemic according to the learning outcomes The researchers used of means and Independent-Samples $\mathrm{T}$ Test as follows. The results showed in table(5).

\section{Table5}

Independent-Samples T Test of responses of students to the questionnaire

\begin{tabular}{|c|c|c|c|c|c|c|c|}
\hline Variables & Faculty & No. & Mean & Std deviation. & $\mathbf{T}$ & Sig.(2-tailed) & df \\
\hline \multirow{2}{*}{$\begin{array}{l}\text { The cognitive aspect of } \\
\text { distance learning }\end{array}$} & Tourism and hotels & 234 & 3.48 & 0.62 & \multirow{2}{*}{2.212} & \multirow{2}{*}{0.027} & \multirow{2}{*}{511} \\
\hline & Education & 279 & 3.36 & 0.64 & & & \\
\hline \multirow{2}{*}{$\begin{array}{l}\text { The emotional aspect of } \\
\text { distance learning }\end{array}$} & Tourism and hotels & 234 & 3.24 & 0.83 & \multirow{2}{*}{2.113} & \multirow{2}{*}{0.035} & \multirow{2}{*}{511} \\
\hline & Education & 279 & 3.07 & 0.89 & & & \\
\hline \multirow{2}{*}{$\begin{array}{l}\text { The skill aspect of distance } \\
\text { learning }\end{array}$} & Tourism and hotels & 234 & 3.28 & 0.72 & \multirow{2}{*}{1.487} & \multirow{2}{*}{0.138} & \multirow{2}{*}{511} \\
\hline & Education & 279 & 3.18 & 0.79 & & & \\
\hline \multirow{2}{*}{$\begin{array}{l}\text { The social aspect of } \\
\text { distance learning }\end{array}$} & Tourism and hotels & 234 & 3.43 & 0.77 & \multirow{2}{*}{1.996} & \multirow{2}{*}{0.111} & \multirow{2}{*}{511} \\
\hline & Education & 279 & 3.32 & 0.79 & & & \\
\hline \multirow{3}{*}{$\begin{array}{l}\text { Barriers to distance } \\
\text { learning }\end{array}$} & Tourism and hotels & 234 & 3.85 & 0.58 & \multirow{3}{*}{0.911} & \multirow{3}{*}{0.363} & \multirow{3}{*}{511} \\
\hline & Education & 279 & 3.80 & 0.54 & & & \\
\hline & Education & 234 & 3.47 & 0.48 & & & \\
\hline \multirow{2}{*}{ Total } & Tourism and hotels & 279 & 3.36 & 0.48 & \multirow{2}{*}{ 2. 450} & \multirow[t]{2}{*}{0.015} & \multirow{2}{*}{511} \\
\hline & Faculty & 234 & 3.48 & 0.62 & & & \\
\hline
\end{tabular}

From the previous table, it is noticed that there are statistically significant differences between the responses of students from the faculties of Tourism and Education in the cognitive aspect of distance learning and the emotional aspect of distance learning and in the questionnaire as a whole, where the level of significance was less than 0.05 , while there were no statistically significant differences between students' responses in faculties of Education and Tourism in the skill aspect of distance learning; the social aspect of distance learning; and barriers to distance learning. Figure 3 indicates some results
Results in figure (3) shows grand mean of the responses of faculty staff in the faculty of Education regarding distance education was 3.36 and grand mean of the responses of faculty staff in the Faculty of Tourism regarding distance education was 3.47.

The previous findings give proof of the invalidity of the second hypothesis that "There are no statistically significant differences between the attitudes of students of the faculties of (Education, Tourism and Hotels) at Fayoum University towards the experience of Distance learning in light of the Corona pandemic, according to their learning outcomes"

\section{Figure 3}

Difference between the responses of students in the Faculties of Education and Tourism regarding distance education

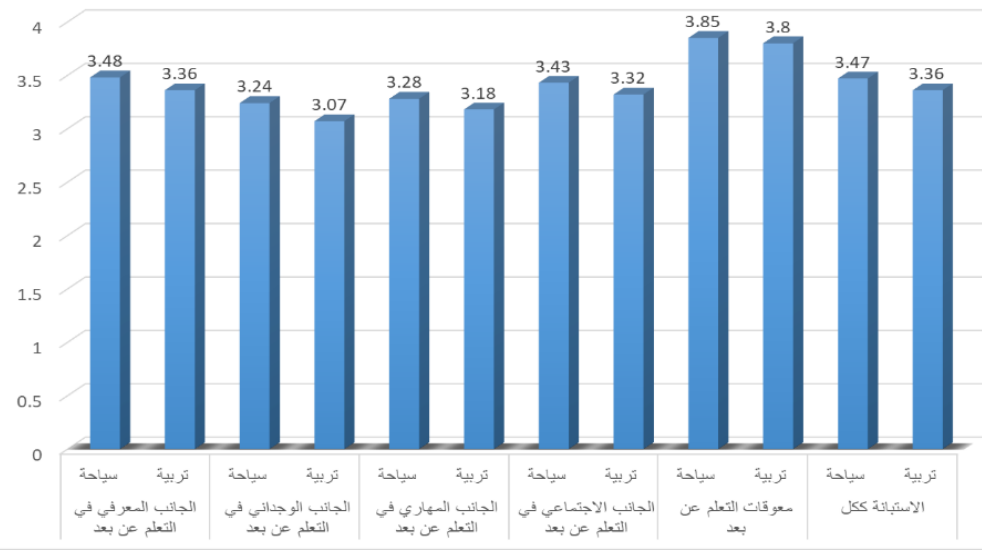




\section{Results \&Discussions}

The research has reached the following results:

Through the findings of the study: The researchers believe that the application of distance learning In light of the Corona pandemic, has helped in making correct decisions in the field of planning, implementation and evaluation of all aspects of learning for both faculty staff and students in the two faculties (education \& tourism and hotels) Where the opinions of the faculty staff were gathered in each of The Faculty of Education: as a faculty that obtained recent academic accreditation in 2020, and the Faculty of Tourism and Hotels as a faculty that obtained academic accreditation with the oldest date of 2015; however, the distance learning experience in light of the Corona pandemic has contributed to achieving a set of educational advantages in all elements of the curriculum system and the educational process for faculty staff and their assistants in the following aspects:

1. Accomplishing the educational objectives related to the course.

2. Being able to communicate the academic content to the student, and the student's positive participation in its understanding as support and encouragement of an active learning style centered on the student and his preferences.

3. Providing the use of a variety of educational methods for distance learning that were not available in traditional learning.

4. The distance learning experience allowed diversity in the method of teaching followed by the faculty staff in addition to the electronic process scripts on which the Teaching staff assistants were trained in the two faculties, with a focus on the diversity of electronic educational activities that were assigned to students, which were undoubtedly not available before Activating and employing distance learning method.

5. As for evaluation methods in distance learning; It varied through the forms of pre, interim, and post-learning evaluation, in addition to activating the electronic evaluation and correction service for students' tests, and the ease of interpretation of students' results, such as providing quick feedback on students' responses to electronic evaluation systems.

6. As for the educational institution's support for the distance learning experience, the opinions of the faculty staff and the assisting body differed, and most of their opinions and responses were based on the neutral response, indicating an acceptable degree of dissatisfaction, to seriously and firmly support the educational institution for the distance learning experience and evaluate its results.

7. The faculty staff and their assistants faced a set of obstacles regarding the distance learning experience, the most important of which was the absence of direct interaction between the faculty staff and the student, which in turn reduces the effectiveness of the learning process this is consistent with a study of( Vlasenko\& Bozhok ,2014) Which confirmed that one of the main disadvantages of distance education is the loss of interaction with other students in the classroom. In distance learning, study in a group is difficult, one just has to do it by himself which becomes publicly one-off as there is no communication with other classmates .also the problem of sudden power outages which prevents the completion of the educational process. The absence of a distance learning culture for some faculty staff and the absence of an efficient internet for some students.

The responses and opinions of the students of the two faculties towards aspects of their learning in light of the distance learning experience in light of the Corona pandemic came as follows:

1. For skills related to the cognitive aspect of distance learning; Most of the opinions of the students of the two faculties believe that the skills of the cognitive side in learning have been achieved, and the experience of distance learning has contributed to providing them with a set of cognitive skills in learning and comprehending the course.

2. As for skills related to the emotional aspect in light of the distance learning experience; The opinions and responses of students in the two faculties were generally unsatisfactory. Since it stood at the neutral response; This explains why they are not convinced of the growth in their emotional skills through the distance learning experience. The researchers attribute this to a number of reasons:

a) The bad psychological state experienced by staffs of the university community as a whole, whether (faculty staff or Teaching staff assistants, students, or even the administrative 
side working in it) due to the spread of the pandemic and the period of recovery or the suspension of the educational process; Which accompanied this period of feelings of frustration, fear and depression of varying severity from time to time; As a result of the bad news that was emerging in the local and global community as a result of that pandemic.

b) The university community's unwillingness and surprise with the experiment; Due to exceptional circumstances; This made a large number of faculty staff reject the experiment and carry negative feelings towards it, especially in the field of using modern social media in this experiment, and without any doubt, the inability of some faculty staffs to use and employ these modern methods of learning made them against it a negative trend; This trend, of course, was attached to the student through the interaction of the faculty staff with him.

c) Lack of motivation of some students, especially those who live in rural areas in Fayoum Governorate, especially some students of the Faculty of Education; As a result of poor electronic services in those villages; Which made them suffer in electronic communication; Consequently, they have negative feelings and their motivation towards the distance learning experience is diminished.

d) some students and as a result of their being suffering from some psychological conditions that result in the inability to communicate information through electronic communication methods through audio and video programs; Which will reflect negatively on their selfconfidence. Consequently, their emotional side is reduced.

3. The results were related to the development of the skills side of the students. Most of the students 'opinions and attitudes appear in the impartial response as well. This is explained from the researchers' point of view that it is an unsatisfactory response to the distance learning experience in this aspect, and they explain this from their views as follows:

a) It is difficult for some students, through elearning and modern social media, through distance learning, to answer some applications and exercises in practical courses.

b) Some students suffer from their inability to write quickly and fluently using some computer programs. This became a difficult skill for students.

c) There was difficulty among students, especially students of scientific departments in the Faculty of Education (Physics - Mathematics - Science - Chemistry - Biology, in understanding some scientific issues and decisions, as well as students of the Faculty of Tourism and Hotels in understanding some math courses such as accounting and statistics, due to the rigid scientific nature that he overcame those decisions, which required great effort in explanation and clarification by the teacher and the interaction between him and the students face to face.

d) Some students suffer from learning difficulties in electronic literacy and writing. As a result, some students were late in implementing electronic assignments related to the academic courses in the two faculties in a fast and accurate manner.

e) The large number of distractions that the student may be exposed to through training in a set of skillful practical skills such as: critical listening, and good listening to lectures; Where this skill may be hindered by the disconnection of the voice, or the departure of a student from the lecture for any reason, which results in the student's delay in acquiring and developing that skill in learning.

4. As for students' answers and responses to the social skills they have acquired; The result of the distance learning experience in light of the Corona pandemic; Most of their responses and opinions were in agreement. This indicates the development of social skills and effective social communication methods.

\section{Recommendations and implication}

\subsection{Recommendations}

Based on the findings of the current study, researchers recommend the following:

- The university must provide a strong internet, with high speeds, and enable each faculty staff and assistants of the faculty staff, and students to set up and open their own account with a user name and password, with the possibility of accessing the knowledge bank at any time; For further cognitive and scientific knowledge; There is no doubt that this is consistent with Egypt's sustainable development strategy and 
2030 vision in the direction of activating digital learning.

- Holding continuous courses and training for the latest electronic educational systems and programs reached by advanced education systems worldwide, and training faculty staffs, their assistants and students on a regular and continuous basis.

- The role of the lecturer in the distance learning process shouldn't be marginalized. Rather, a hybrid or integrated learning culture and system that combines the two forms of pure elearning and mixed e-learning must be adopted in order for a great benefit to occur to the learner.

- The university launches faster in the field of electronic calendar service, speeds up completion of what is known as electronic exams, and activates question bank services; In order to facilitate the evaluation of students in the time of any sudden crisis, and not to get confused and random in student evaluation systems.

- The necessity of adopting an organized plan with specific goals and a carefully planned plan in the field of employing distance learning services in the educational process, and applying them firmly, and subjecting any party to the educational process to legal accountability in the event of failure to implement it fully.

- Attempting to activate live broadcast services, and use some educational platforms with participatory group cooperation; In order to provide an element of interaction between the lecturer and the student; As it is present in traditional learning systems, and not allowing the faculty staff to make the academic content available to students in a rigid text format, he completely lacks the elements of attraction, suspense, positive motivation, and various influences that increase the student's motivation towards the process and experience of remote learning.

- The necessity to direct students not to be busy while online teaching them, and to inflict the appropriate penalty on the student who is negligent or preoccupied with interacting with the lecturer. Who took advantage of the opportunity not to see the lecturer face to face through the various distance learning means and services.

- The lecturer mustn't focus on a single electronic service and repeats it on an ongoing basis in explaining the parts of his course. This makes distance learning boring and uncomfortable for the student and weakens his motivation towards learning through it.

- Attempting to provide the university with educational platforms, and sites for storing and uploading files on it, with a large capacity to absorb information, and upload students' files to them, and their various assignments, without any effort on the part of the faculty staff or the student.

- When designing online courses; It should be taken care to provide the elements that raise the level of interaction with the presented scientific material, such as designing the site, organizing its contents in a logical and attractive manner, and providing multimedia such as pictures, audio, flashes, presentations, and others.

- Development of university faculties regulations; To add distance learning courses as undergraduate and bachelor degree programs to serve the labor market, according to the experiences of advanced European universities in this field.

- Evaluating the experience level of students wishing to study remotely, via the Internet; To determine the necessary experience in using the Internet before starting the study.

- Accelerate at a measured pace; To find practical and effective solutions to sudden problems that lead to suspension of the study.

- Spreading the culture of distance education in the university community on a regular basis, indicating its importance, and directing developed countries and relying on it in the near future.

\subsection{Implications}

This study contributes to spreading the culture of distance learning in higher education institutions, according to Egypt's sustainable development strategy 2030, which supports the philosophy of distance learning.

The present study may be useful for the following: 
1. Determining the different attitudes for each of the faculty staff in the Faculties of Education, Tourism and Hotels at Fayoum University, in addition to the students' attitudes in each of the two faculties considering the outcomes of learning that they acquired in light of the Corona pandemic.

2. Discovering the relationship between university community trends for students of the Faculties of Education, Tourism and Hotels at Fayoum University towards a distance learning experience considering the Corona pandemic.

3. Identifying the benefits and disadvantages of distance learning considering the Corona pandemic in the university community.

4. Providing a list of the most important outcomes of learning that can be developed through distance learning may benefit experts specializing in university teaching.

Demonstrate the importance of cooperative work among staff of the various faculties at Fayoum University, especially those faculties that obtain academic accreditation, such as: Faculty of Education, Tourism and Hotels at Fayoum University.

\section{Reference}

Adnan, M., \& Anwar, K. (2020). Online Learning amid the COVID-19 Pandemic: Students' Perspectives. Online Submission, 2(1), 45-51 .

Almanthari, A., Maulina, S., \& Bruce, S. (2020). Secondary School Mathematics Teachers' Views on E-learning Implementation Barriers during the COVID-19 Pandemic: The Case of Indonesia. Eurasia Journal of Mathematics, Science and Technology Education, 16(7), em1860 .

Alqahtani, A. Y., \& Rajkhan, A. A. (2020). E-Learning Critical Success Factors during the COVID-19 Pandemic: A Comprehensive Analysis of ELearning Managerial Perspectives. Education Sciences, 10(9), 216 .

Allan, J.(1996). Learning outcomes in higher education. Studies in Higher Education, 21,(1).

Arkorfu, Valentina\&Abaidoo, Nelly(2015). The role of e-learning, advantages and disadvantages of its adoption in higher education, International Journal of Instructional Technology and Distance Learning, Vol. 12. No.1.

Bloom,B.S(1965). Taxonomy of educational objectives: the classification of educational goals. New York: David McKay.

Dhawan, S. (2020). Online learning: A panacea in the time of COVID-19 crisis. Journal of Educational Technology Systems, 49(1), 5-22 .
European Centre for the Development of Vocational Training (Cedefop) (2011). When defining learning outcomes in curricula, every learner matters. Briefing note, March - April 2011.

European Centre for the Development of Vocational Training (Cedefop) (2017). Defining, writing and applying learning outcomes: A European handbook. Luxemburg : Publications office

El gahsh, , Nahid Fouad\& Diab, Gehan Mohamed Abd El-Hamed(2020). E-learning During COVID-19 Pandemic: Obstacles Faced Nursing Students and Its Effect on Their Attitudes While Applying It, American Journal of Nursing Science, Vol. 9, No. 4, pp. 295-309.

El-Seoud, M., El-Sofany ,H. F., Taj-Eddin, I. A., Nosseir, A., \& El-Khouly, M. M. (2013). Implementation of Web-Based Education in Egypt through Cloud Computing Technologies and Its Effect on Higher Education. Higher Education Studies, 3(3), 62-76.

El-Seoud, S., Taj-Eddin, I., Seddiek, N., Ghenghesh, P., \& El-Khouly, M. (2014). The impact of e-learning on Egyptian higher education and its effect on learner's motivation: A case study. Computer Science and Information Technology, 2(3), 179187.

El Gamal, S., \& Abd El Aziz, R. (2011).The Perception of Students' Regarding E-Learning Implementation in Egyptian Universities. Paper presented at the The Fifth International Conference on Digital Society, eL\&mL.

Eisner, E.W. (1979). The educational imagination: On the design and evaluation of school programs. Macmillan, New York, Ny.

Engzell,per, Frey, Arun and Verhagena, Mark(2020). Learning inequality during the COVID-19 pandemic. UK Economic and Social Research Council (ESRC) and Nuffield Faculty.

Haider, A. S., \& Al-Salman, S. (2020). Dataset of Jordanian university students' psychological health impacted by using e-learning tools during COVID19. Data in brief, 32, 106104 .

Kaur, K., \& Zoraini Wati, A. (2004). An assessment of e-learning readiness at Open University Malaysia. , 1017-1022.

Kennedy, D. (2006). Writing and using learning outcomes: A practical guide, Cork, University Faculty Cork

Koohang, A., \& Harman, K.(2005). Open source: A metaphor for e-learning. Informing Science, 8 .

Kumar Basak, S., Wotto, M., \& Belanger, P. (2018). Elearning, M-learning and D-learning: Conceptual definition and comparative analysis. E-Learning and Digital Media, 15(4), 191-216 .

Lwoga, Edda(2012). Making learning and Web 2.0technologies work for higherlearning institutions in Africa, Muhimbili University of Health and 
Allied Sciences, Dar es Salaam,United Republic of Tanzania

Merriam Webster Dictionary and Thesaurus (2006). Defining learning, Merriam Webster Inc.

Mohamad M.M.; Sulaimanb N.L.; Sern L.C.; and Sallehd K.M., (2015), Malaysia Measuring the Validity and Reliability of Research Instruments, 4th World Congress on Technical and Vocational Education and Training (WoCTVET), 5th-6th November 2014,Procedia - Social and Behavioral Sciences),PP. $164-171$.

Nusche, D. (2008). Assessment of learning outcomes in higher education: A comparative review of selected practices, OECD education working papers, No, 15, OECD publishing.project report, Unit for the development of adult, Continuing education( UDACE).

Otter, S. (1992). Learning outcomes in higher education, A development project report, Unit for the development of adult, Continuing education( UDACE).

Park, S. Y. (2009). An analysis of the technology acceptance model in understanding university students' behavioral intention to use e-learning. Journal of Educational Technology \& Society, 12(3), 150-162.

Posner, G. J. (1992). Analyzing the curriculum, McGraw Hill, USA.

Radha, R., Mahalakshmi, K., Kumar, V. S., \& Saravanakumar, A. (2020). E-learning during lockdown of Covid-19 pandemic: a global perspective. International journal of control and automation, 13(4), 1088-1099 .

Shehzadi, S., Nisar, Q. A., Hussain, M. S., Basheer, M. F., Hameed, W U., \& Chaudhry, N. I. (2020). The role of digital learning toward students' satisfaction and university brand image at educational institutes of Pakistan: a post-effect of COVID-19. Asian Education and DevelopmentStudies.

Sahrawi, A., \& Shabouh, N.,( 2018). Emotional Objectives, the major absent in teaching, why teachers do not care about emotio

أحمد، ريهام مصطفي محمد (YT) (Y): توظيف التعلم

الإلكترونى لتحقيق معايير الجودة في العملية التعلمية،

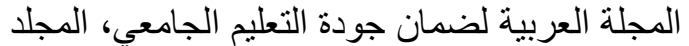

الخامس، العدد 9.

حياه، قز ادرى (9 1 ـ ب): ضو ابط ومعايير الجودة في التعليم

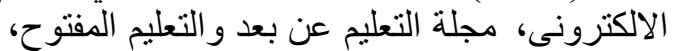
جامعة بني سويف.

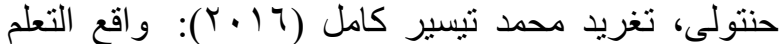
الإلكتروني في جامعة النجاح الوطنية ودوره في

تحقيق التفاعل بين المتعلمين من وجهة نظر طلية طلبة كلية

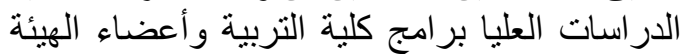

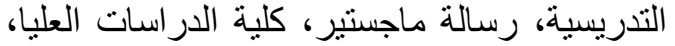
جامعه النجاح الوطنية، فلسطين. 